Vol. 2, No. 2, 2019

\author{
A/ V. Slyuzar ${ }^{1}$, S. V. Khomyak ${ }^{2}$, Ya. A. Kalymon ${ }^{1}$ \\ Lviv Polytechnic National University, \\ ${ }^{1}$ Department of Chemistry and Technology of Inorganic Substances, \\ ${ }^{2}$ Department of Technology of Biologically Active Substances, Pharmacy and Biotechnology. \\ semkhom@ukr.net
}

\title{
THE INFLUENCE OF EXPOSURE TIME ON CHANGING OF THE PROPERTIES OF THE SODA SOLUTION OF QUINHYDRONE DURING THE QUINHYDRONE CATALYST PREPARATION
}

https://doi.org/10.23939/ctas2019.02.068

Change of the properties of soda solution of quinhydrone during their exposure in the presence of air has been investigated by the methods of cyclic voltammetry and spectroscopy (IR and UV). It has been shown that in the process of exposure of the solution occurs the process of quinhydrone oligomerization and changes its redox properties. The redox potential of the solution increases, the $\mathrm{pH}$ decreases, the currents of oxidation peaks decrease and completely dampen, indicating the stabilization of the properties of the oligomer. It has been established that the oxidizing forms of the oligomer are still present in the quinhydrone catalyst solution for more than 8 years and the solution does not lose oxidizing properties to chemisorbed hydrogen sulfide.

Key words: quinhydrone, carbonate solution, oligomerization, exposure time, redox properties.

\section{Introduction}

A significant area of application of oxidationreducing properties of quinone compounds is liquidphase catalytic (oxidative) methods for gases purification from hydrogen sulfide [1-3]. These methods consist of chemisorption of hydrogen sulfide from gases by alkaline solutions with simultaneous oxidation of chemosorbed hydrogen sulfide to sulfur by an oxidizer, which is a component of the absorbing solution. Industrial significance in the processes of gases purification from hydrogen sulfide has a redox system based on derivatives of naphtha- and anthraquinones [3].

In the quinhydrone method of gases purification from hydrogen sulfide, an oxidizer is used based on quinhydrone $[1,4]$ - quinhydrone catalyst. It is obtained by oligomerization of benzoquinhydrone in an alkaline solution. The oxidationreducing properties of the quinhydrone catalyst are very important for the process of the gases purification from hydrogen sulfide. After all, during the purification of gases in the absorbent solution should be rapid oxidation of chemisorbed $\mathrm{H}_{2} \mathrm{~S}$ by quinhydrone catalyst to sulfur

$$
\mathrm{H}_{2} \mathrm{~S}+\mathrm{Na}_{2} \mathrm{CO}_{3} \Leftrightarrow \mathrm{NaHS}+\mathrm{NaHCO}_{3},
$$$$
\mathrm{NaHS}+\mathrm{NaHCO}_{3}+\{\mathrm{Q}\}=\mathrm{S}+\mathrm{Na}_{2} \mathrm{CO}_{3}+\{\mathrm{Q}\} \mathrm{H}_{2},
$$

and then the quinhydrone catalyst should be quickly regenerated by the air oxygen

$$
\{\mathrm{Q}\} \mathrm{H}_{2}+1 / 2 \mathrm{O}_{2}=\{\mathrm{Q}\}+\mathrm{H}_{2} \mathrm{O}
$$

where $\{\mathrm{Q}\}$ i $\{\mathrm{Q}\} \mathrm{H}_{2}-$ its oxidizing (quinone) and reducing (hydroquinone) form, respectively.

The basic regularities of quinhydrone oligomerization were established earlier [4-6]. It is shown that in the time of exposure of alkaline solution of quinhydrone there is the formation of semiquinone radicals, the growth of the polymer chain and the transition of monomeric semiquinone radicals into stable polysemiquinones. Oligomeric products, in comparison with not oligomerized quinhydrone, have higher selectivity relative to the oxidation of chemosorbed $\mathrm{H}_{2} \mathrm{~S}$ to sulfur, and have lower selectivity to by-products such as sodium thiosulfate or other sulfur compounds

$$
2 \mathrm{NaHS}+2 \mathrm{O}_{2}=\mathrm{Na}_{2} \mathrm{~S}_{2} \mathrm{O}_{3}+\mathrm{H}_{2} \mathrm{O} \text {. }
$$

The output of oligomeric products is influenced by the concentration of quinhydrone, the exposure time, the presence of air oxygen, the type of alkaline component $\left(\mathrm{NaOH}, \mathrm{NaHCO}_{3}\right.$ and $\mathrm{Na}_{2} \mathrm{CO}_{3}$ ), its stoichiometric ratio to quinhydrone [4, 6]. The exposure time of the quinhydrone solution is one of the most important factors. As shown by studies [4], unstable semiquinones that formed at the 
The influence of exposure time on changing of the properties of the soda solution of quinhydrone during...

initial moment of quinhydrone oligomerization can interact with sodium sulfite or thiosulfate, which are present in the absorbent solution and sulfonated quinone compounds are formed. These compounds, as compared to the unsubstituted ones, have a higher oxidative-reduction potential (ORP), which reduces the selectivity of $\mathrm{H}_{2} \mathrm{~S}$ oxidation to sulfur.

For the processes of purification of vents gases from the $\mathrm{H}_{2} \mathrm{~S}$, the quinhydrone catalyst is obtained under the following conditions: the ratio of molar concentration of alkali to quinhydrone $2: 1$, the exposure time of solution with direct access of air oxygen for 5 days. The resulting solution of the catalyst is used to prepare the quinhydrone absorbent solution of the composition, $\mathrm{g} / \mathrm{dm}^{3}: \mathrm{Na}_{2} \mathrm{CO}_{3}-10$, quinhydrone - 5 and $\mathrm{Na}_{2} \mathrm{~S}_{2} \mathrm{O}_{3}-200$ [6]. However, the above-described conditions for the oligomerization of quinhydrone do not always prevent the formation of sulfonated quinone compounds, especially in quinhydrone solutions with elevated concentrations of components [7]. In addition, preliminary studies of the redox properties of the quinhydrone catalyst solutions by the voltammetric method showed [8] that the solution still does not completely stabilize these properties after 5 days of exposure.

Therefore, the purpose of the research was to study the change of oxidation-reducing properties of the concentrated solution of quinhydrone in the exposure time during its oligomerization.

\section{Materials and methods}

To study the properties of compounds, which have oxidative-reduction properties, electrochemical methods are often used, namely the method of cyclic voltammetry (CV) [9]. Investigation of the change of oxidation-reducing properties of quinhydrone carbonate solution was carried out in potentiodynamic conditions by potentiostat PI-50-1.1. In this case, the working and auxiliary electrodes were Pt, and the comparison electrode was $\mathrm{Ag} / \mathrm{AgCl}$. The working anode area was $0.84 \mathrm{~cm}^{2}$. Terms of research: temperature $20{ }^{\circ} \mathrm{C}$, sweep rate $-20 \mathrm{mV} / \mathrm{s}$, direction - to the anode side.

For preparation of the investigated solutions, the quinhydrone was of chemically pure grade. The solutions of quinhydrone (concentrations of quinhydrone $25 \mathrm{~g} / \mathrm{dm}^{3}$ and sodium carbonate $50 \mathrm{~g} / \mathrm{dm}^{3}$, molar ratio of $\mathrm{Na}_{2} \mathrm{CO}_{3}$ to quinhydrone is $4: 1$ ) were obtained for 1, 5, 30 and more than 3000 days with direct access of air and periodic stirring.

The alkalinity of the investigated solutions was measured by $\mathrm{pH}$-meter $\mathrm{pH}-373 \mathrm{M}$. Infrared, ultraviolet and visible spectroscopy techniques were used to explain the changes of redox properties. IR and UV spectra were obtained on the Specord M 80 and Specord M 40, respectively. The IR spectra of quinhydrone were obtained in a $\mathrm{KBr}$ tablet, and oligomer solutions in a thin, dried film on $\mathrm{KBr}$ glass.

\section{Results and discussion}

Determine the direction of potential sweep.

Characteristic CV curves of the quinhydrone catalyst solution are shown in Fig. 1. The curves show the following differences. In the investigated limits of potentials, there is one anode peak on a curve with sweep direction to the anode side and two anode peaks on a curve with a sweep direction to the cathode side. Potentials of peaks are different.

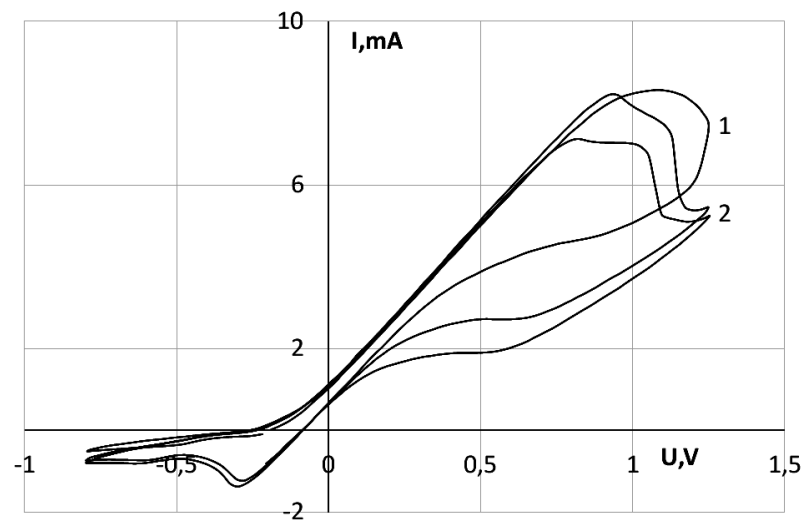

Fig. 1. CV curves of a freshly prepared solution of the quinhydrone catalyst: 1 - sweep direction of potential to the anode side (1 cycle); 2 - sweep direction to the cathode side (2 cycles)

On the curve with a sweep direction to the anode side, there is one cathode peak at a potential of $\sim 0.3 \mathrm{~V}$. On the curve with the sweep direction to the cathode side in 1st cycle, this peak is not present, but it appears in 2nd cycle of this curve. The cathodic peak is observed for practically the same potential, but the values of the current of the cathode peaks are different. The absence of a peak on the CV curve of the 1 st cycle indicates an anode activation of the catalyst and/or the appearance of an "oxidic form", 


\section{A V. Slyuzar ', S. V. Khomyak', Ya. A. Kalymon}

which is then reduced on the cathode [9]. In existing sources of literature, there is no mention of such features of quinones solutions research [10-14]. It is obvious that this "oxidic form" is semiquinone radicals $[11,12]$. All subsequent $\mathrm{CV}$ studies were carried out with the sweep direction to the anode side to account for the cathodic peak.

\section{Effect of the exposure time of the solution}

Characteristic curves of $\mathrm{CV}$ solutions during their exposure are presented in Fig. 2. Results of researching are summarized in Table 1.

As the results of the research have shown, with the increase of the exposure time of the quinhydrone solution, its $\mathrm{pH}$ is reduced from 10.3 to 9.4 and the ORP increases from -200 to $-150 \mathrm{mV}$. Such ORP of the catalyst solution and not high $\mathrm{pH}$ will contribute to the selective oxidation of $\mathrm{H}_{2} \mathrm{~S}$ to $\mathrm{S}$.

The peaks of oxidation $\left(\mathrm{I}_{\mathrm{pa}}\right)$ and the corresponding recovery peaks $\left(\mathrm{I}_{\mathrm{pc}}\right)$ are observed on the CV curves. The potentials of the oxidation peaks $\left(E_{p a}\right)$ are shifted to the left, the currents of the oxidation peaks decrease and fade with an increase in the exposure time. In this case, the potentials of the recovery peaks $\left(E_{p c}\right)$ shifted to the right, while the currents of the recovery peaks decrease, however, after 30 days and up to $\sim 8$ years, they remain at the level of $0.2 \ldots 0.15 \mathrm{~mA}$, which corresponds to a current density of $0.024 \ldots 0.018 \mathrm{~A} / \mathrm{dm}^{2}$. That is, the quinhydrone solution shows the immutable oxidizing properties, regardless of the exposure time.

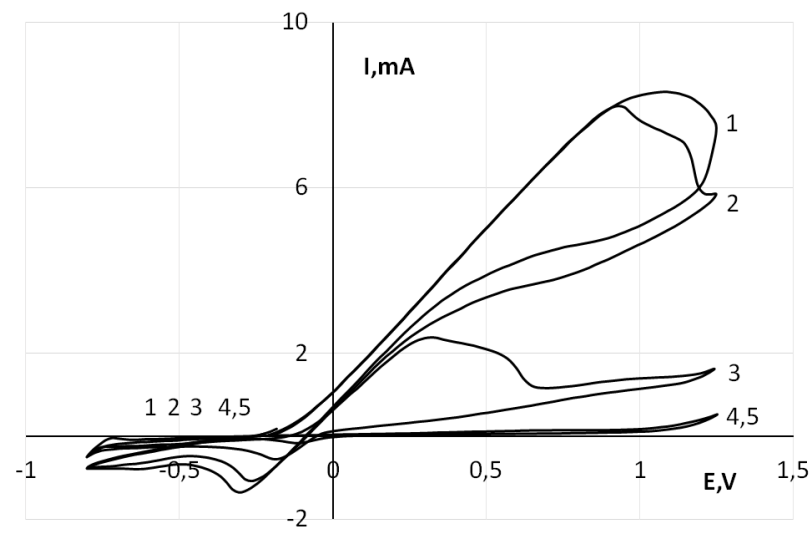

Fig. 2. CV curves of quinhydrone solution in the exposure time, days: $1-0$ (1 hour); $2-1 ; 3-5 ; 4-30 ; 5-\sim 3000$
In the solution of the obtaining catalyst for 30 and more days, the oxidation peaks disappearing (within the limits of the potentials of $0.3 \ldots 0.6 \mathrm{~V}$ ), which for the solution after exposure of 5 days is not characteristic. Such solution will not demonstrate reduction properties for potentials $\sim \mathrm{V}$. The currents peak on $\mathrm{CV}$ curves for $\sim 1 \mathrm{~V}$ or more may obviously be related to the release of $\mathrm{O}_{2}$ in an alkaline solution.

In the process of exposure the solution, obviously, there is oxidation of reducing forms of oligomers. However, at 5 days of exposure in a solution with a concentration of quinhydrone $25 \mathrm{~g} / \mathrm{dm}^{3}$, compared to a solution of $5 \mathrm{~g} / \mathrm{dm}^{3}$ [6], the recovery forms of the catalyst are still present. As already indicated, this may lead to the formation of sulfonated quinone compounds [4]. Since the intensification of oligomerization process through the forced bubbling of air through the solution does not completely replace the required exposure time [6], then with increasing concentration of quinhydrone in solution it is necessary to expose this solution during $5 \ldots 10$ days for the complete disappearance of reducing forms of the catalyst.

An important result of the research is that the carbonate solution of quinhydrone has not lost its oxidizing properties for 8 years and its biological pollution has not occurred.

\section{Investigation of $\mathrm{UV}$ and visible spectra}

Dissolution of quinhydrone in aqueous carbonate solution is accompanied by a color change.

First, the solution is brown with a gray-green tint, and then becomes bright brown. The comparison of the quinhydrone spectra in aqueous and carbonate solutions was performed because the quinhydrone in carbonate solution subjected to the oligomerization.

The comparison of the spectra of aqueous solutions of quinhydrone (freshly prepared and 3 days after the beginning of dissolution) in the ultraviolet and visible regions was showed that these solutions are characterized in the UV region by a absorption band with two maxima: $\pi \rightarrow \pi^{*}$ electronic transitions in 246 and $288 \mathrm{~nm}$ (intensity ratio 6:1). These maxima correspond to electronic transitions in the hydroquinone and quinone fragments. Then in the visible region of the spectrum, only the slopes of the fall-off band reach up to $600 \mathrm{~nm}$ inclusively without a clearly expressed maximum. 
The influence of exposure time on changing of the properties of the soda solution of quinhydrone during...

Table 1

Influence of the exposure time on the properties of the quinhydrone catalyst solution

\begin{tabular}{|c|c|c|c|c|c|c|c|}
\hline No. & Exposure time, days & $\mathrm{pH}$ & $\mathrm{ROP}, \mathrm{V}$ & $\mathrm{E}_{\mathrm{pc}}, \mathrm{V}$ & $\mathrm{I}_{\mathrm{pc}}, \mathrm{mA}$ & $\mathrm{E}_{\mathrm{pa}}, \mathrm{V}$ & $\mathrm{I}_{\mathrm{pa}}, \mathrm{mA}$ \\
\hline 1 & 0 (1 hour) & 10.30 & -0.202 & -0.305 & 4.46 & 1.088 & 8.32 \\
\hline 2 & 1 & 10.10 & -0.195 & -0.264 & 3.11 & 0.929 & 7.98 \\
\hline 3 & 5 & 9.45 & -0.155 & -0.185 & 0.54 & 0.320 & 2.39 \\
\hline 4 & 30 & 9.41 & -0.153 & -0.120 & 0.18 & - & - \\
\hline 5 & $\sim 3000$ & 9.40 & -0.152 & -0.116 & 0.16 & - & - \\
\hline
\end{tabular}

Two maximums also appear in the UV spectrum of the freshly prepared carbonate solution of quinhydrone, with the second maximum being characterized by an increase in intensity (hyper effect, intensity ratio 2:1) and some $4 \mathrm{~nm}$ hypsohromic shift. This indicates an increase in the proportion of quinone fragments in the oligomer. In addition, in the visible region of the spectrum, in this slow slump, a small shoulder appears in the range of 520-580 nm, which, obviously, causes the greengray tint of the color of the solution. This absorption can be attributed to $n \rightarrow \pi^{*}$ transitions in the monoanion radicals of quinhydrone, the "initiators" of the polymerization chain. Investigation of this solution after 1 day of its exposure under air oxygen present showed that the shoulder in the downward range in the range of 520-580 $\mathrm{nm}$ disappears, but the absorption band becomes more intense (hyper effect) due to increasing the length of the chain. In the UV region, there is one wide absorption maximum within the range $250-290 \mathrm{~nm}$, which corresponds to the absorption of polysemiquinones. The solution of the quinhydrone catalyst becomes bright brown and then does not change its color.

\section{Investigation of IR spectra}

Investigation of infrared spectra of quinhydrone and its carbonate solutions helped to study the process of catalyst formation. The change in the ratio of the quinone and hydroquinone components in the reaction system was determined by the corresponding signals of the carbonyl and hydroxyl groups.

In the IR spectra of the initial quinhydrone, there is a highly intense narrow absorption band with a maximum of $3248 \mathrm{~cm}^{-1}$, which corresponds to the hydroxyl group stretch. This kind of strip means that there are no intermolecular hydrogen bonds in the crystalline quinhydrone. Absorption is also present at $1632 \mathrm{~cm}^{-1}$ (bond $\mathrm{C}=\mathrm{O}$ ), $1468 \mathrm{~cm}^{-1}(\mathrm{C}-\mathrm{C}), 1256$ and $1216 \mathrm{~cm}^{-1}$ (C-O) [15].

IR spectra of solution of oligomeric products of quinhydrone on 5th day of exposure are also characterized by absorption bands of hydroxyl groups and aromatic nucleus. However, they are manifested in the form of wider signals, which can be explained by the formation of polycondensation systems. In the wavelength range $3600-3000 \mathrm{~cm}^{-1}$ (maximum at $3440-3300 \mathrm{~cm}^{-1}$ ) there is an intensive absorption band of stretch of the associated hydroxyl groups, indicating the presence of strong inter- and intra-molecular hydrogen bonds in the oligomer product. The absorption band with a maximum at $1705-1710 \mathrm{~cm}^{-1}$ can be attributed to the carbonyl groups $(\mathrm{C}=\mathrm{O})$ stretch formed during of polymerrization and oxidative processes. The intensity of the absorption band at $1472 \mathrm{~cm}^{-1}$ has increased, which corresponds to the $\mathrm{C}-\mathrm{C}$ bond stretch.

The compound of the quinone and hydroquinone fragments in the oligomerized product is carried out by means of the C-C bond, but not by the formation of the phenylene oxide $(\mathrm{C}-\mathrm{O})$ groups, as the absorption band of the latter in the region of $1210-1260 \mathrm{~cm}^{-1}$ is absent. The presence in the macromolecule of condensed aromatic fragments directly linked to the $\mathrm{C}-\mathrm{C}$ bond with the quinone causes a high degree of complementarity of the macromolecules and provides the possibility of electrons delocalization along the conjugated chain, which provides the "softness" of the oxidizing properties. These and other studies [4] give reason to propose an approximate structure of the quinhydrone catalyst in oxidizing and reducing forms (Fig. 3).

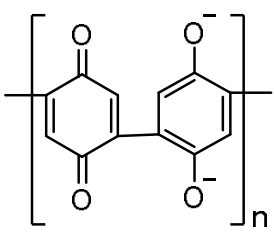

I

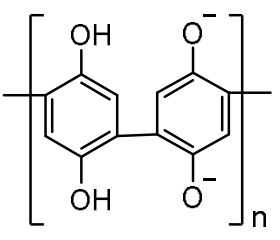

II
Fig. 3. Schematic structure of quinhydrone oligomers (oxidizing (I) and reducing (II) forms, $n=1 \ldots 4$ )

\section{Conclusions}

The formation of a quinhydrone catalyst takes place through the step of producing semiquinone radicals, their gradual polymerization with the formation of polysemiquinones and the growth of the polymer chain, which is confirmed by voltammetry and spectrophotometric methods of analysis. By the 


\title{
A V. Slyuzar ${ }^{1}$, S. V. Khomyak ${ }^{2}$, Ya. A. Kalymon
}

exposure time, the ORP of the quinhydrone solution (concentration of quinhydrone $25 \mathrm{~g} / \mathrm{dm}^{3}$ and sodium carbonate $50 \mathrm{~g} / \mathrm{dm}^{3}$ ) an increase from -200 to $-150 \mathrm{mV}$ and $\mathrm{pH}$ - decrease from 10.3 to 9.4. In the atmosphere of air, the reducing forms of a quinhydrone catalyst are gradually oxidized, but this process is not completely finished in 5 days. If the concentration of quinhydrone in the solution (within $5 \ldots .25 \mathrm{~g} / \mathrm{dm}^{3}$ ) increases, it is necessary to provide the exposure time 5...10 days for the complete disappearance of reducing forms of the catalyst. The oxidizing properties of the catalyst also decrease by the exposure time. However, the quinhydrone catalyst does not lose its oxidizing properties during 8 years of exposure.

\section{References}

1. Slyuzar, A. V., Znak, Z. O., Kalymon, Ya. A., \& Bukliv, R. L. (2019). Metody ochyshchennia i pereroblennia sirkovodenvmisnykh haziv (ohliad) [Methods of purification and processing of hydrogen sulfide-containing gases: a review.] Voprosy Khimii $i$ Khimicheskoi Tekhnologii - Issues of Chemistry and Chemical Technology, 3, 83-97. [in Ukrainian].

2. Kohl, A. L., \& Nielsen, R. B. (1997). Gas Purification. Houston: Gulf Publishing Company.

3. Yavorskiy, V., Slyuzar, A., \& Kalymon, Ya. (2016). Sulfur gas production in Ukraine (review). Chemistry and Chemical Technology, 10, 4(s), 613-619.

4. Znak, Z. O. (1992) Intensyfikatsiia i optymizatsiia khinhidronnoho metodu ochystky haziv vid sirkovodniu $\mathrm{z}$ oderzhanniam sirky - [Intensification and optimization of the quinhydrone purification method from hydrogen sulfide to sulfur production: (Extended abstract of Candidate's thesis). Lviv. [in Ukrainian].

5. Znak, Z. O., Yavorskiy, V. T., \& Levashova, V. L. (1990). Protcess polimerizatcii khingidrona V shchelochnoi srede. Kinetika $i$ kataliz - Kinetics and catalysis, 31, 1, 197-202. [in Russian].

6. Yavorskiy, V. T., Kalymon, Ya. A., Znak, Z. O., \& Chaiko, N. Y. (2000). Tekhnolohiia pryhotuvannia pohlynalnoho rozchynu na osnovi khinhidronu dlia ochyshchennia haziv vid sirkovodniu // Ekotekhnologii $i$ resursosberezhenie - Ecotechnology and resource-saving, 5, 56-59. [in Ukrainian].

7. Yavorskiy, V. T., Slyuzar, A. V., Mertsalo, I. P., Kalymon, Ya. A. (2011). Vplyv metodyky pryhotuvannia khinhidronnoho rozchynu ochyshchennia haziv vid sirkovodniu na yoho fizyko-khimichni i okysno-vidnovni vlastyvosti. Voprosy Khimii i Khimicheskoi TekhnologiiIssues of Chemistry and Chemical Technology, 4(2), 301304 [in Ukrainian].

8. Yavorskiy, V. T., Slyuzar, A. V., Kalymon Ya. A., \& Mertsalo, I. P. (2005). Elektrokhimichni vlastyvosti khinhidronu v luzhnomu rozchyni. Visnyk NTU "Kharkivskyi politekhnichnyi instytut", 16, 166-169. [in Ukrainian].

9. Danylov, F. Y., \& Protsenko, V. S. (2016). Liniina ta tsyklichna voltamperometriia - Linear and cyclic voltammetry. Dnipro: LIRA. [in Ukrainian].

10. Rafiee, M., \& Nematollahi D. (2007). Voltammetry of Electroinactive Species Using Quinone/ Hydroquinone Redox: A Known Redox System Viewed in a New Perspective. Electroanalysis, 19(13), 1382-1386.

11. Guin, P. S., Das, S. \& Mandal, P. C. (2011) Electrochemical Reduction of Quinones in Different Media: A Review. International Journal of Electrochemistry, 1-22.

12. Rojas de Astudillo L., Rivera L., Brito-Gómez R. \& Tremont R. J. (2010). Electrochemical study of 1,4benzoquinone on gold surface modified Journal of Electroanalytical Chemistry, 56-60.

13. Anamul Haque, M., Muhibur Rahman, M. \& Abu Bin Hasan Susan, M. (2011). Aqueous Electrochemistry of Anthraquinone and Its Correlation with the Dissolved States of a Cationic Surfactant. Journal of Solution Chemistry, 40(5), 861-875.

14. May Quan, Sanchez, D., Wasylkiw M. F., \& Smith D. F. (2007). Voltammetry of Quinones in Unbuffered Aqueous Solution: Reassessing the Roles of Proton Transfer and Hydrogen Bonding in the Aqueous Electrochemistry of Quinones. Journal of the American Chemical Society. 129, 42, 12847-12856.

15. Skoog, D. A., \& Holler, F. J. (2007). Principles of Instrumental Analysis. Australia: Thomson Brooks.

\author{
А. В. Слюзар ${ }^{1}$, С. В. Хом'як ${ }^{2}$ Я. А. Калимон ${ }^{1}$ \\ Національний університет “Львівська політехніка”, \\ ${ }^{1}$ кафедра хімії і технології неорганічних речовин, \\ 2 кафедра технології біологічно активних сполук, фармації та біотехнології
}

\section{ВПЛИВ ЧАСУ ЕКСПОЗИЦІЇ НА ЗМІНУ ВЛАСТИВОСТЕЙ КАРБОНАТНОГО РОЗЧИНУ ХІНГІДРОНУ В ПРОЦЕСІ ПРИГОТУВАННЯ ХІНГІДРОННОГО КАТАЛІЗАТОРА}

Методами ЦВА, ІЧ та УФ спектроскопії досліджено содові розчини хінгідрону під час їх вистоювання (експозиції) за доступу повітря. Показано, що в процесі вистоювання розчину відбувасться олігомеризація хінгідрону і зміна його окисно-відновних властивостей. У часі вистоювання редокс потенціал розчинів зростає, рН знижусться, зменшуються і повністю загасають струми піків окиснення, що вказує на стабілізацію властивостей олігомера. Встановлено, що за часу вистоювання понад 8 років у розчині хінгідронного каталізатора присутні окисні форми, і такий розчин не втрачає окисних властивостей щодо хемосорбованого сірководню.

Ключові слова: хінгідрон, карбонатний розчин, олігомеризація, час експозиції, окисно-відновні властивості. 